Research Article

\title{
Pollution and Risk Assessment of Heavy Metals in the Sediments and Soils around Tiegelongnan Copper Deposit, Northern Tibet, China
}

\author{
Yuhu Luo $\mathbb{D}^{1,2,3,4}$ and Qinxian Jia $\mathbb{D D}^{5}$ \\ ${ }^{1}$ Shaanxi Provincial Land Engineering Construction Group Co. Ltd., Xi'an 710075, China \\ ${ }^{2}$ Institute of Land Engineering \& Technology, Shaanxi Provincial Land Engineering Construction Group Co. Ltd., \\ Xi'an 710075, China \\ ${ }^{3}$ Key Laboratory of Degraded and Unused Land Consolidation Engineering, The Ministry of Natural Resources, \\ Xi'an 710075, China \\ ${ }^{4}$ Shaanxi Provincial Land Consolidation Engineering Technology Research Center, Xi'an 710075, China \\ ${ }^{5}$ Key Laboratory of Saline Lake Resources and Environments, Ministry of Natural Resources, Institute of Mineral Resources, \\ Chinese Academy of Geological Sciences, Beijing 100037, China
}

Correspondence should be addressed to Qinxian Jia; jia-qinxian@sohu.com

Received 24 July 2021; Revised 7 October 2021; Accepted 21 October 2021; Published 5 November 2021

Academic Editor: Khaled Mostafa

Copyright ( 92021 Yuhu Luo and Qinxian Jia. This is an open access article distributed under the Creative Commons Attribution License, which permits unrestricted use, distribution, and reproduction in any medium, provided the original work is properly cited.

\begin{abstract}
The surface sediments of the Rongna River and the surface soils around the Tiegelongnan copper deposit were collected, and the heavy metals $\mathrm{Cu}, \mathrm{Zn}, \mathrm{Pb}, \mathrm{Cr}, \mathrm{Cd}, \mathrm{As}, \mathrm{Hg}$, and $\mathrm{Ni}$ were measured for their concentrations and health risk assessment. When the Rongna River passed through the $\mathrm{Cu}$ deposit area, the concentrations of $\mathrm{Cu}, \mathrm{Zn}, \mathrm{As}, \mathrm{Cd}, \mathrm{Ni}$, and $\mathrm{Hg}$ in the surface sediments increased significantly, and the concentrations of $\mathrm{Cu}, \mathrm{Zn}$, and As exceeded the corresponding Grade II environmental quality standard. The heavy metals in the soil of the mining area were greater than the background value of the soil in Tibet. The geoaccumulation index indicated that the sediments of the river entering the mining area were very highly polluted by Cu and moderately polluted by $\mathrm{Cd}$ and $\mathrm{Zn}$, and the soils in the mining area were moderately polluted by $\mathrm{Cu}$. The potential ecological risk (PER) indices revealed that the sediments of the river entering the mining area had significantly high ecological risks, while the PER of the sediments away from the river section of the mining area was low, and the PER of the soils around the Cu deposit was moderate. The results of the health risk assessment indicated that the noncarcinogenic risks of heavy metals in sediments and soil of the mining area were within the acceptable range for adults and children. However, the carcinogenic risk of As and Cd in the sediment and As in the soil exceeds the relevant national standards, which may pose a certain risk to human health.
\end{abstract}

\section{Introduction}

With the development of society and the acceleration of industrialization, a large amount of heavy metals such as copper $(\mathrm{Cu})$, lead $(\mathrm{Pb})$, zinc $(\mathrm{Zn})$, arsenic $(\mathrm{As})$, cadmium $(\mathrm{Cd})$, chromium $(\mathrm{Cr})$, nickel $(\mathrm{Ni})$, and mercury $(\mathrm{Hg})$ enter the sediment and soil [1-4]. Because heavy metals easily accumulate in the environment, are not degradable, and have strong bioavailability, by entering the environment, they can easily enter the human body through the food chain. [5-7]. Some heavy metals, such as $\mathrm{Zn}$ and $\mathrm{Cu}$, are beneficial to human health, are important mineral elements in body organs, and play a vital role, but they may be toxic and even cause mental illness when ingested in excess $[8,9]$. Other heavy metals have only serious toxic effects on the human body. For example, As exposure is related to skin cancer, liver cancer, lung cancer, and kidney cancer, and it has been listed in the first category of carcinogens by the World Health Organization [10-13]; Hg may permanently damage the brain, liver, and other organs through oral 
ingestion, inhalation, or dermal contact. Long-term lowdose exposure to $\mathrm{Hg}$ in pregnant women may cause fetal Minamata disease [14]; long-term exposure to $\mathrm{Pb}$ may lead to various cardiovascular diseases and even carcinogenesis $[15,16]$; $\mathrm{Cr}$ intake is closely related to breast cancer death [17]; Cd is one of the causes of chronic kidney disease [18]. A small amount of $\mathrm{Cd}$ intake may lead to a decrease in bone density, thereby increasing the risk of osteoporosis and fractures $[19,20]$. Long-term $\mathrm{Ni}$ exposure may cause skin diseases [21], and severe cases may cause various respiratory diseases [22-24].

Highly toxic heavy metals are easily stored in river sediments or soil in various ways [25-27]. Heavy metals entering sediments have adverse effects on river ecosystems due to their high toxicity, resistance to decomposition, and bioaccumulation $[28,29]$. At the same time, sediments are one of the sources of heavy metal pollution in rivers. When environmental conditions change, the heavy metals deposited in the sediments will be released again, which will increase the concentration of heavy metals in the water, and various aquatic animals and plants living in the water will be poisoned by heavy metals [30,31]. The heavy metals present in the soil can be transferred to groundwater, plants, and the atmosphere [32]. Moreover, heavy metals in the soil directly threaten human health through oral ingestion, inhalation, and dermal contact [33]. Therefore, for potential heavy metal pollution areas, pollution evaluation and prevention are particularly important.

Northern Tibet is rich in metal mineral resources and is a fragile ecological environment $[34,35]$. The sediments and soils distributed in the mining area are extremely vulnerable to heavy metal pollution [36-40]. The Tiegelongnan copper mine is located in Wuma Township, Gaize County, Northern Tibet, and the main minerals are chalcopyrite, pyrite, bornite, magnetite, sphalerite, and malachite [41]. The ore deposit has not yet been mined, but a part of the ore body is exposed to the air naturally, which easily releases a large amount of heavy metals into the sediment or soil under the action of weathering $[42,43]$. The Rongna River is a major river in the mining area that provides drinking water for wild animals and livestock that frequent the area. Once it is polluted, it will cause serious harm to animals and nearby herders. However, the current research on the health risk assessment of heavy metal pollution in sediments and soils in Tibet is mainly concentrated around Lhasa and other major cities, while research on remote mining areas in northern Tibet is relatively lacking [44-46]. Therefore, this study measured the concentration of heavy metals $(\mathrm{Cu}, \mathrm{Zn}$, $\mathrm{Pb}, \mathrm{Cr}, \mathrm{Cd}, \mathrm{As}, \mathrm{Hg}$, and $\mathrm{Ni}$ ) in the surface sediments and soils of the Rongna River in the Tiegelongnan copper deposit area to analyze the pollution degree. On this basis, the ecological risks and human carcinogenic and noncarcinogenic health risks of heavy metals in sediments and soils were evaluated to provide necessary data support for the protection of the ecological environment of mining areas.

\section{Materials and Methods}

The Tiegelongnan copper mine is located in Wuma Township, Gaize County, Northern Tibet. It lies between $83^{\circ} 23^{\prime} \mathrm{E}$ to $83^{\circ} 27^{\prime} \mathrm{E}$ longitude and $32^{\circ} 47^{\prime} \mathrm{N}$ to $32^{\circ} 50^{\prime} \mathrm{N}$ latitude. The altitude is $4,800-5,100 \mathrm{~m}$. The study area has a plateau subtropical semiarid monsoon climate. The temperature difference between day and night is large. The annual average temperature is $-0.1^{\circ} \mathrm{C}$ to $-2.5^{\circ} \mathrm{C}$. The annual rainfall is $308.3 \mathrm{~mm}$, and the rainy season is concentrated in July and August. The Tiegelongnan copper mine is a largescale polymetallic sulfide deposit with an average $\mathrm{Cu}$ grade of $0.64 \%$. The copper resources exceed $400 \times 10^{4} \mathrm{t}$. The metal minerals include chalcopyrite, pyrite, bornite, magnetite, sphalerite, blue chalcocite, and malachite [41].

The Rongna River develops in the upper mountain spring and flows through the Tiegelongnan copper mine. The river water eventually flows into Bie Co (Figure 1). Accordingly, eight river surface sediment samples $(0-10 \mathrm{~cm})$ from the reach of the Rongna River that did not enter the Tiegelongnan copper deposit area (R1) until the end of the river (R8) were collected. $\mathrm{R} 1$ will be used to refer to the reach of the river that has not entered the $\mathrm{Cu}$ deposit area; R2-R6 refer to the reaches near the deposit area; and R7 and R8 refer to the reaches far away from the deposit. The distances between the R1-R6 sample points were approximately $1,000 \mathrm{~m}$; the distance between R6 and R7 was approximately $4,000 \mathrm{~m}$; and the distance between R7 and R8 was approximately $8,000 \mathrm{~m}$. The surface sediments of the Bolong River (BL) far away from the Tiegelongnan copper deposit area were collected as a control. Six surface soil samples were collected at $50 \mathrm{~m}$ intervals from the top (S1) to the bottom (S6) of the hillside in the Tiegelongnan copper deposit area. All sediment and soil samples were sealed immediately after collection and stored below $5^{\circ} \mathrm{C}$. After being transported back to the laboratory, the samples were air-dried and then ground through a $0.15 \mathrm{~mm}$ mesh screen to remove impurities such as grit for analysis.

The sediment and soil samples were digested by microwave using the US EPA 3050B method. Then, an inductively coupled plasma mass spectrometer system (ICPMAS, PE300D) was used to measure the concentrations of the heavy metals $\mathrm{Cu}, \mathrm{Pb}, \mathrm{Zn}, \mathrm{As}, \mathrm{Cd}, \mathrm{Cr}$, and $\mathrm{Ni}$ [47]. The mercury in the samples was digested with $\mathrm{HNO}_{3}-\mathrm{H}_{2} \mathrm{SO}_{4}$ and then measured with an atomic fluorescence spectrometer (AFS-9760) [48]. The test methods were analyzed and quality controlled by the national soil component analysis standard reference materials, and the standard samples used on the machine were all prepared with national standard materials. The recovery rates of heavy metal contents in standard reference materials were between $90 \%$ and $110 \%$.

\section{Evaluation Method}

3.1. Geoaccumulation Index $\left(I_{G e o}\right)$. The geoaccumulation index was proposed by the German scientist Muller in 1969 [49]. It was first used to evaluate the pollution status of heavy metals in sediments, and later, it was also used to evaluate the pollution status of heavy metals in soil. Its expression is shown in the following equation:

$$
I_{\mathrm{Geo}}=\log _{2}\left(\frac{C_{i}}{k B_{i}}\right)
$$




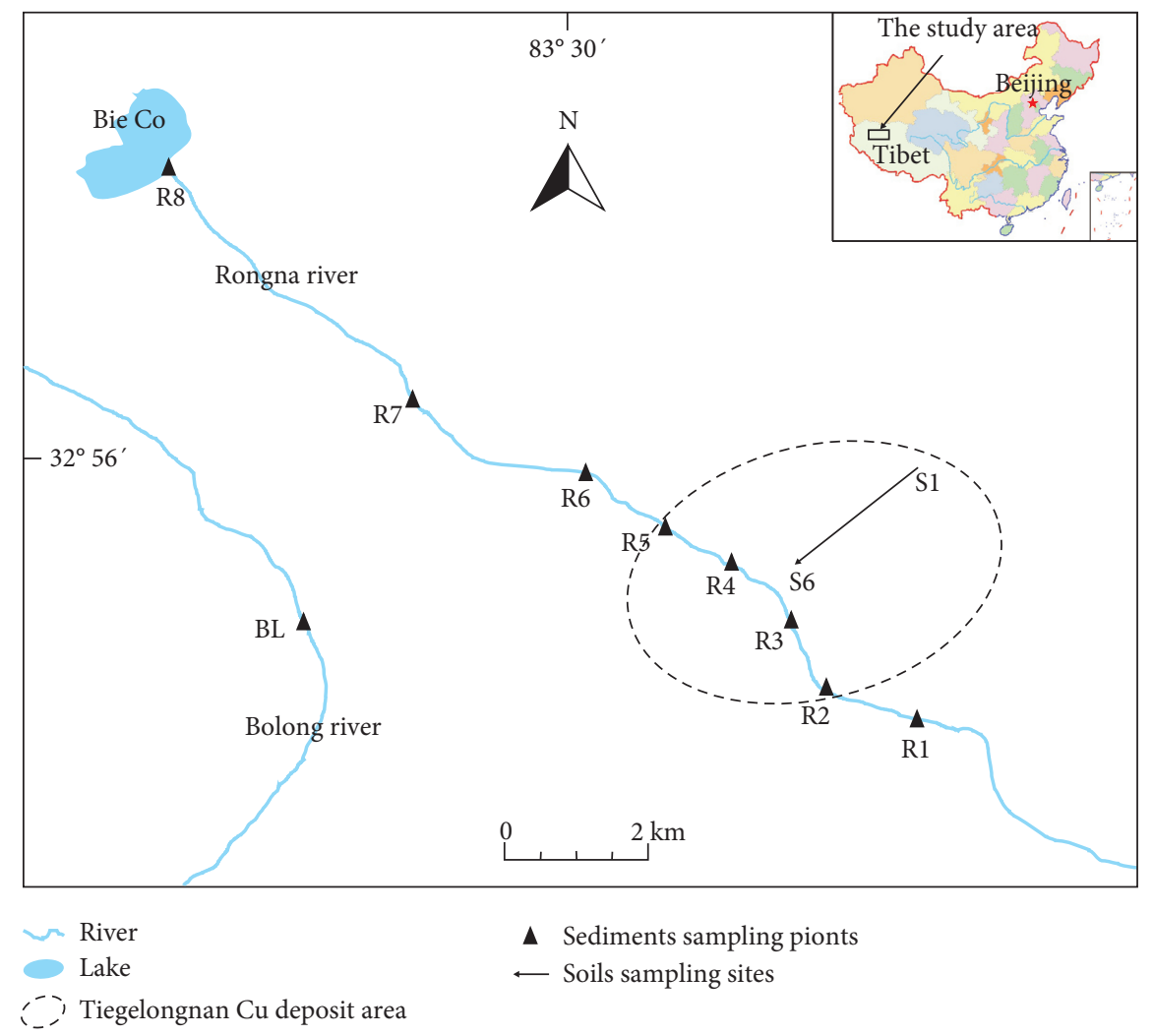

FIGURE 1: Location of the study area and sampling sites.

where $C_{i}$ is the measured concentration of heavy metal $i$, in $\mathrm{mg} / \mathrm{kg} ; B_{i}$ is the geochemical background value of heavy metal $i$, referring to Zhang's research, that is, $\mathrm{Cu}=19.6 \mathrm{mg} /$ $\mathrm{kg}, \quad \mathrm{Pb}=27.6 \mathrm{mg} / \mathrm{kg}, \quad \mathrm{Zn}=70.7 \mathrm{mg} / \mathrm{kg}, \quad \mathrm{As}=16.2 \mathrm{mg} / \mathrm{kg}$, $\mathrm{Cd}=0.074 \mathrm{mg} / \mathrm{kg}, \quad \mathrm{Cr}=68 \mathrm{mg} / \mathrm{kg}, \quad \mathrm{Ni}=27.8 \mathrm{mg} / \mathrm{kg}, \quad$ and $\mathrm{Hg}=0.021 \mathrm{mg} / \mathrm{kg}$ [50]; and $k$ is a constant, generally $k=1.5$. According to the value of $I_{\mathrm{Geo}}$, the pollution degree can be divided into seven grades, as shown in Table 1.

3.2. Potential Ecological Risk Assessment (PER). The potential ecological risk index method was proposed by the Swedish scientist Hakanson in 1980 [51]. This method evaluates heavy metal pollution in soils or sediments from the perspective of sedimentology according to the nature of heavy metals and environmental behavior characteristics. While considering the content of heavy metals in the soil, this method links the ecological and environmental effects of heavy metals with toxicology and can more accurately represent the impact of heavy metals on the ecological environment [52]. The expressions are shown in the following equations:

$$
\begin{aligned}
C_{f}^{i} & =\frac{C_{s}^{i}}{C_{n}^{i}}, \\
E_{r}^{i} & =T_{r}^{i} \times C_{f}^{i}, \\
\mathrm{RI} & =\sum_{i=1}^{n} E_{r}^{i},
\end{aligned}
$$

TABLE 1: Geoaccumulation index classification.

\begin{tabular}{lcc}
\hline$I_{\text {geo }}$ & Pollution level & Pollution degree \\
\hline$I_{\mathrm{Geo}} \geq 5$ & 6 & Very highly polluted \\
$4 \leq I_{\mathrm{Geo}}<5$ & 5 & Highly polluted \\
$3 \leq I_{\mathrm{Geo}}<4$ & 4 & Moderately to highly polluted \\
$2 \leq I_{\mathrm{Geo}}<3$ & 3 & Moderately polluted \\
$1 \leq I_{\mathrm{Geo}}<2$ & 2 & Moderately polluted to unpolluted \\
$0 \leq I_{\mathrm{Geo}}<1$ & 1 & Unpolluted \\
$I_{\mathrm{Geo}}<0$ & 0 & Background concentration \\
\hline
\end{tabular}

where $C_{f}^{i}$ is the pollution coefficient of a heavy metal $i$; $C_{s}^{i}$ is the measured value of soil heavy metal $i$ concentration, mg/ $\mathrm{kg}$; and $C_{n}^{i}$ is the background value of soil elements, and the background value in this study uses the background value of Tibetan soil elements [50]. $E_{r}^{i}$ is the potential ecological risk index of a single element; $T_{r}^{i}$ is the toxic response parameter of heavy metal $i$. According to the standard established by Hakanson, the toxic response coefficient of heavy metals is $\mathrm{Hg}=40, \mathrm{Cr}=2, \mathrm{Cd}=30, \mathrm{As}=10, \mathrm{~Pb}=5, \mathrm{Cu}=5, \mathrm{Zn}=1$, and $\mathrm{Ni}=5$. RI is the potential ecological risk index of a variety of heavy metals. The potential ecological risk index classification is shown in Table 2.

3.3. Health Risk Assessment (HRA). Heavy metal health risk assessment aims to evaluate the carcinogenic and noncarcinogenic risks of the human body after full exposure to heavy metals. The main exposure routes of soil heavy metals to the human body are oral ingestion, breathing inhalation, and skin contact [33]. Heavy metals in sediments mainly 
TABle 2: Classification of potential ecological risk index.

\begin{tabular}{lccccc}
\hline Ecological risk level & Low & Moderate & Considerable & High & Significantly high \\
\hline$E_{r}^{i}$ & $<40$ & $40-80$ & $80-160$ & $160-320$ & $>320$ \\
RI & $<150$ & $150-300$ & $300-600$ & $\geq 600$ & - \\
\hline
\end{tabular}

affect human health through ingestion and skin contact [53]. According to the relevant standards of the Chinese Ministry of Environmental Protection and American publications (US EPA) [54-57], the average daily doses (ADDs) of heavy metals under the three exposure routes are estimated by the following equations:

$$
\begin{aligned}
\mathrm{ADD}_{\text {ingestion }} & =\frac{C \times R_{\text {ing }} \times \mathrm{EF} \times \mathrm{ED}}{\mathrm{BW} \times \mathrm{AT}} \times 10^{-6}, \\
\mathrm{ADD}_{\text {inhalation }} & =\frac{C \times R_{\text {inh }} \times \mathrm{EF} \times \mathrm{ED}}{\mathrm{PEF} \times \mathrm{BW} \times \mathrm{AT}} \times 10^{-6}, \\
\mathrm{ADD}_{\text {dermal }} & =\frac{C \times \mathrm{SA} \times \mathrm{SL} \times \mathrm{ABF} \times \mathrm{EF} \times \mathrm{ED}}{\mathrm{BW} \times \mathrm{AT}} \times 10^{-6}, \\
\mathrm{HI} & =\sum \mathrm{HQ}=\sum \frac{\mathrm{CDI}}{\mathrm{RfD}}, \\
\mathrm{TCR} & =\sum \mathrm{CR}=\sum \mathrm{CDI} \times \mathrm{CSF},
\end{aligned}
$$

where $C$ is the concentration of heavy metals in the soil, $R_{\mathrm{ing}}$ is the daily intake of heavy metals in soil, $R_{\text {inh }}$ is the daily inhalation rate, $\mathrm{EF}$ is the exposure frequency, $\mathrm{ED}$ is the exposure duration, $\mathrm{BW}$ is the average body weight, $\mathrm{AT}$ is the average time, and PEF is the release factor of particulates. SA is the exposed area of the skin; SL is the skin adhesion factor; and $\mathrm{ABF}$ is the skin adsorption factor. The parameters in the formulas are shown in Table 3, and Table 4 shows the RfD and CSF values $[58,59]$. The hazard quotient (HQ) and hazard index (HI) are used to describe the noncarcinogenic risk of heavy metals. When the value of $\mathrm{HQ}$ or $\mathrm{HI}$ is less than 1 , it means that there is no noncarcinogenic health risk; otherwise, it means there is a potential noncarcinogenic health risk, and the larger the value, the higher the risk. Carcinogenic risk (CR) and total carcinogenic risk index (TCR) are used to describe the carcinogenic risk of heavy metals. When the value of CR or TCR is less than $10^{-6}$, there is no carcinogenic risk. However, when the value of $C R$ or TCR is greater than $10^{-4}$, heavy metals are likely to cause cancer risk to the human body. When the value of $C R$ is between $10^{-6}$ and $10^{-4}$, it indicates that the risk of carcinogenesis is within an acceptable range.

\section{Results and Discussion}

4.1. Heavy Metal Content in Sediment and Soil. Figure 2 shows the characteristics of heavy metal content in the surface sediments of the Rongna River. From the upper reaches of the river to the end, the content of heavy metals in the surface sediments changed significantly. Before the river entered the Tiegelongnan copper deposit area (R1), the content of heavy metals in the sediment was relatively low.
However, after the river entered the ore deposit area (R2-R6), the contents of the heavy metals $\mathrm{Cu}, \mathrm{Zn}, \mathrm{As}, \mathrm{Cd}, \mathrm{Ni}$, and $\mathrm{Hg}$ in the sediments had a significant tendency to increase. Among them, $\mathrm{Cu}, \mathrm{Zn}$, and As exceeded the corresponding Grade II national environmental quality standard: the highest contents of $\mathrm{Cu}$ and As in $\mathrm{R} 2$ were $2,598 \mathrm{mg} / \mathrm{kg}$ and $77.1 \mathrm{mg} / \mathrm{kg}$, and the highest content of $\mathrm{Zn}$ in $\mathrm{R} 5$ was $690 \mathrm{mg} / \mathrm{kg}$. The concentrations of the heavy metals $\mathrm{Pb}, \mathrm{Cd}$, $\mathrm{Cr}, \mathrm{Ni}$, and $\mathrm{Hg}$ in the sediments were all lower than the Grade II standard value.

According to this analysis, when the Rongna River flows through the Tiegelongnan copper deposit area, the content of heavy metals in the surface sediments increases significantly, which indicates that rivers flowing through the mining area are vulnerable to heavy metal pollution $[60,61]$. Because the exposed part of the Tiegelongnan copper mine is higher than the river, a large amount of rain washed over the surface of the mineral in the rainy season, which may bring part of the activated heavy metals in the ore into the Rongna River valley. Therefore, the source of heavy metal pollution in the Rongna River may be formed by the long-term weathering and rain washing of exposed ore bodies. When the minerals were exposed to the air, they were more likely to be weathered to produce some heavy metals [62]. Compared with the Bolong River, which is far away from the mining area, the heavy metals in sediments of the Rongna River are significantly higher than those of the Bolong River. However, at the end of the Rongna River (BC), the heavy metals in the sediments were not greatly affected, which indicated that after a certain distance of self-purification, the heavy metal pollution of the Rongna River was within the normal range [63].

The results in Figure 3 show that from the top to the bottom of the hillside, the heavy metals $\mathrm{Cu}, \mathrm{Cd}$, and $\mathrm{Zn}$ in the soil of the Tiegelongnan copper deposit area had a small tendency to increase. This may be due to the accumulation of heavy metals at the bottom of the hillside under the action of rain erosion. However, the changes in other heavy metal elements in the soil were not obvious. The average concentrations of heavy metals in the soil were less than the corresponding Grade II national environmental quality standard, but except for $\mathrm{Pb}$, they were greater than the elemental background values of soil in Tibet.

4.2. Geoaccumulation Index. Figure 4 shows the geoaccumulation index of $\mathrm{Cu}, \mathrm{Pb}, \mathrm{As}, \mathrm{Zn}, \mathrm{Cd}, \mathrm{Cr}, \mathrm{Ni}$, and $\mathrm{Hg}$ in the sediments of the Rongna River and the soil of the Tiegelongnan copper deposit area. The geoaccumulation index showed that $\mathrm{Cd}$ in the sediment of R1 was moderately polluted, which may be related to the higher background value, and other metals were lightly polluted or nonpolluting. In the sediments of $\mathrm{R} 2-\mathrm{R} 6, \mathrm{Cu}$ was very highly polluted; the $I_{\mathrm{Geo}}$ of $\mathrm{Cu}$ was the largest at $\mathrm{R} 2$, reaching 6.46; 
TABLE 3: Exposure parameters for the health risk assessment models.

\begin{tabular}{|c|c|c|c|}
\hline \multirow{2}{*}{ Parameter } & \multirow{2}{*}{ Unit } & \multicolumn{2}{|c|}{ Value } \\
\hline & & Child & Adult \\
\hline$R_{\text {ing }}$ & $\mathrm{mg} \cdot \mathrm{d}^{-1}$ & 200 & 100 \\
\hline $\mathrm{EF}$ & $d \cdot$ year $^{-1}$ & 350 & 350 \\
\hline ED & years & 6 & 25 \\
\hline BW & $\mathrm{kg}$ & 15.9 & 56.8 \\
\hline \multirow{2}{*}{ AT } & \multirow{2}{*}{ d } & 2,190 (for noncarcinogens) & 9,125 (for noncarcinogens) \\
\hline & & 26,280 (for carcinogens) & 26,280 (for carcinogens) \\
\hline$R_{\text {inh }}$ & $\mathrm{m}^{3} \cdot \mathrm{d}^{-1}$ & 7.5 & 14.5 \\
\hline PEF & $\mathrm{m}^{3} \cdot \mathrm{kg}^{-1}$ & $1.36 \times 10^{9}$ & $1.36 \times 10^{9}$ \\
\hline SA & $\mathrm{cm}^{2}$ & 2,800 & 5,700 \\
\hline SL & $\mathrm{mg} \cdot \mathrm{cm}^{-2}$ & 0.2 & 0.07 \\
\hline \multirow{2}{*}{$\mathrm{ABF}$} & \multirow{2}{*}{-} & 0.001 (for noncarcinogens) & 0.001 (for noncarcinogens) \\
\hline & & 0.01 (for carcinogens) & 0.01 (for carcinogens) \\
\hline
\end{tabular}

TABLE 4: RfD and SF of different exposure pathways of soil heavy metals.

\begin{tabular}{|c|c|c|c|c|c|c|}
\hline \multirow{2}{*}{ Heavy metals } & \multicolumn{3}{|c|}{$\mathrm{RfD}\left(\mathrm{mg} \cdot(\mathrm{kg} \cdot \mathrm{d})^{-1}\right)$} & \multicolumn{3}{|c|}{$\operatorname{CSF}\left((\mathrm{kg} \cdot \mathrm{d}) \cdot \mathrm{mg}^{-1}\right)$} \\
\hline & Ingestion & Inhalation & Dermal & Ingestion & Inhalation & Dermal \\
\hline $\mathrm{Cd}$ & $1.00 \times 10^{-3}$ & $1.00 \times 10^{-5}$ & $1.00 \times 10^{-5}$ & 6.1 & 6.3 & 6.1 \\
\hline $\mathrm{Pb}$ & $3.50 \times 10^{-3}$ & $3.52 \times 10^{-3}$ & $5.25 \times 10^{-4}$ & $8.5 \times 10^{-3}$ & - & - \\
\hline $\mathrm{Cr}$ & $3.00 \times 10^{-3}$ & $2.86 \times 10^{-5}$ & $6.00 \times 10^{-5}$ & - & $4.20 \times 10$ & - \\
\hline $\mathrm{Ni}$ & $2.00 \times 10^{-2}$ & $2.06 \times 10^{-2}$ & $5.40 \times 10^{-3}$ & - & $8.40 \times 10^{-1}$ & - \\
\hline $\mathrm{Cu}$ & $4.00 \times 10^{-2}$ & $4.02 \times 10^{-3}$ & $1.20 \times 10^{-2}$ & - & - & - \\
\hline $\mathrm{Zn}$ & $3.00 \times 10^{-1}$ & $3.00 \times 10^{-1}$ & $6.00 \times 10^{-2}$ & - & - & - \\
\hline $\mathrm{Hg}$ & $3.00 \times 10^{-4}$ & $8.57 \times 10^{-5}$ & $2.10 \times 10^{-5}$ & - & - & - \\
\hline As & $3.00 \times 10^{-4}$ & $1.23 \times 10^{-4}$ & $1.23 \times 10^{-4}$ & 1.5 & $1.51 \times 10$ & 3.66 \\
\hline
\end{tabular}

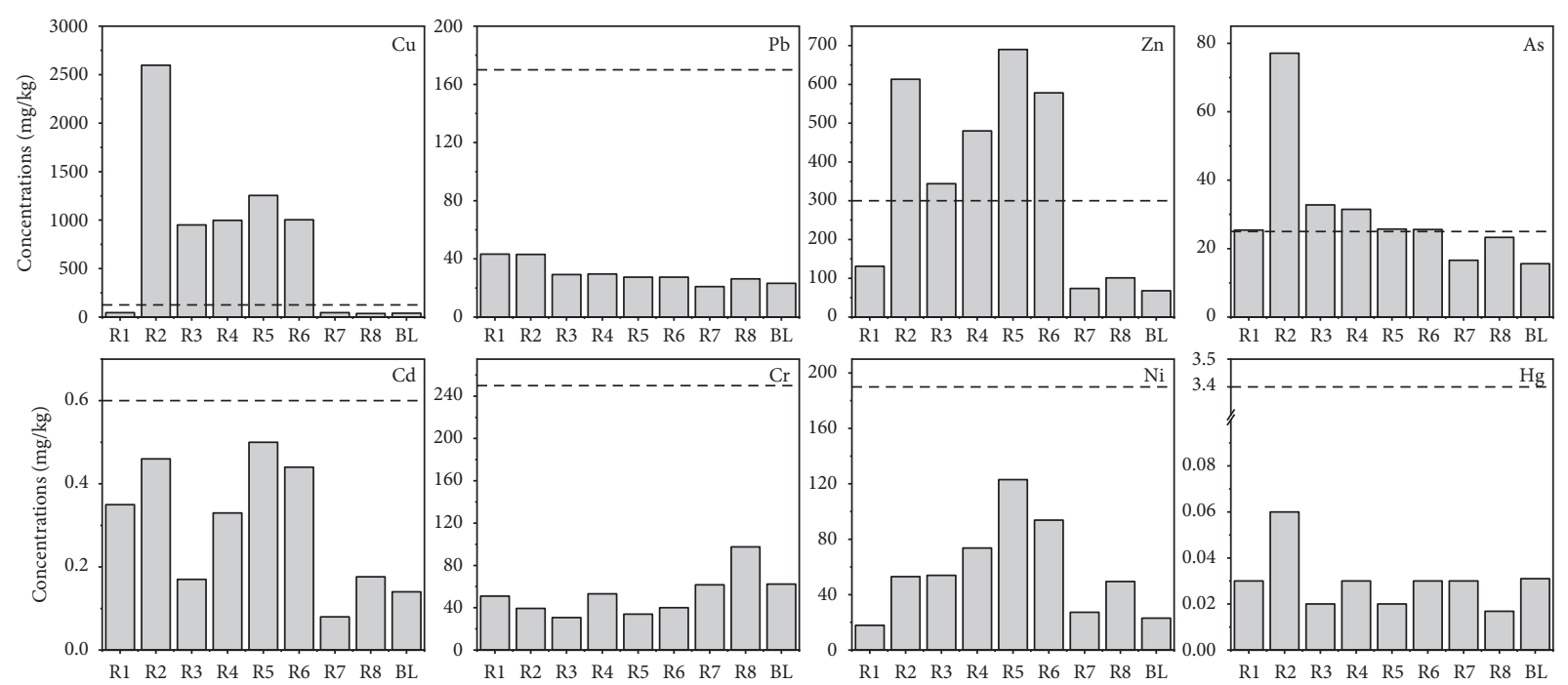

FIgURE 2: Heavy metal content in the sediments of the Rongna River.

Zn was moderately polluted; $\mathrm{Cd}$ in $\mathrm{R} 2, \mathrm{R} 4, \mathrm{R} 5$, and $\mathrm{R} 6$ were moderately polluted to unpolluted; and $\mathrm{Zn}$ in $\mathrm{R} 3$ was moderately polluted. The contents of other heavy metals were unpolluted or close to the background value. In the reach of the Rongna River far away from the deposit area (R7 and R8), the heavy metals in the sediment were unpolluted; the $I_{\mathrm{Geo}}$ of $\mathrm{Cu}$ in the soil was greater than 1 and less than 2, which meant moderately polluted to unpolluted, and the $I_{\mathrm{Geo}}$ of other heavy metals were all less than 1 , which meant unpolluted. The pollution degrees of heavy metals in sediments in mining areas were generally higher than those in soils. The order of $I_{\mathrm{Geo}}$ in the sediments and soils of the mining area from large to small is $\mathrm{Cu}>\mathrm{Cd}>\mathrm{Zn}>$ $\mathrm{As}>\mathrm{Ni}>\mathrm{Hg}>\mathrm{Pb}>\mathrm{Cr}$.

4.3. Potential Ecological Risk Assessment. Figure 5 and Table 5 show the PER index of heavy metals at each sampling 

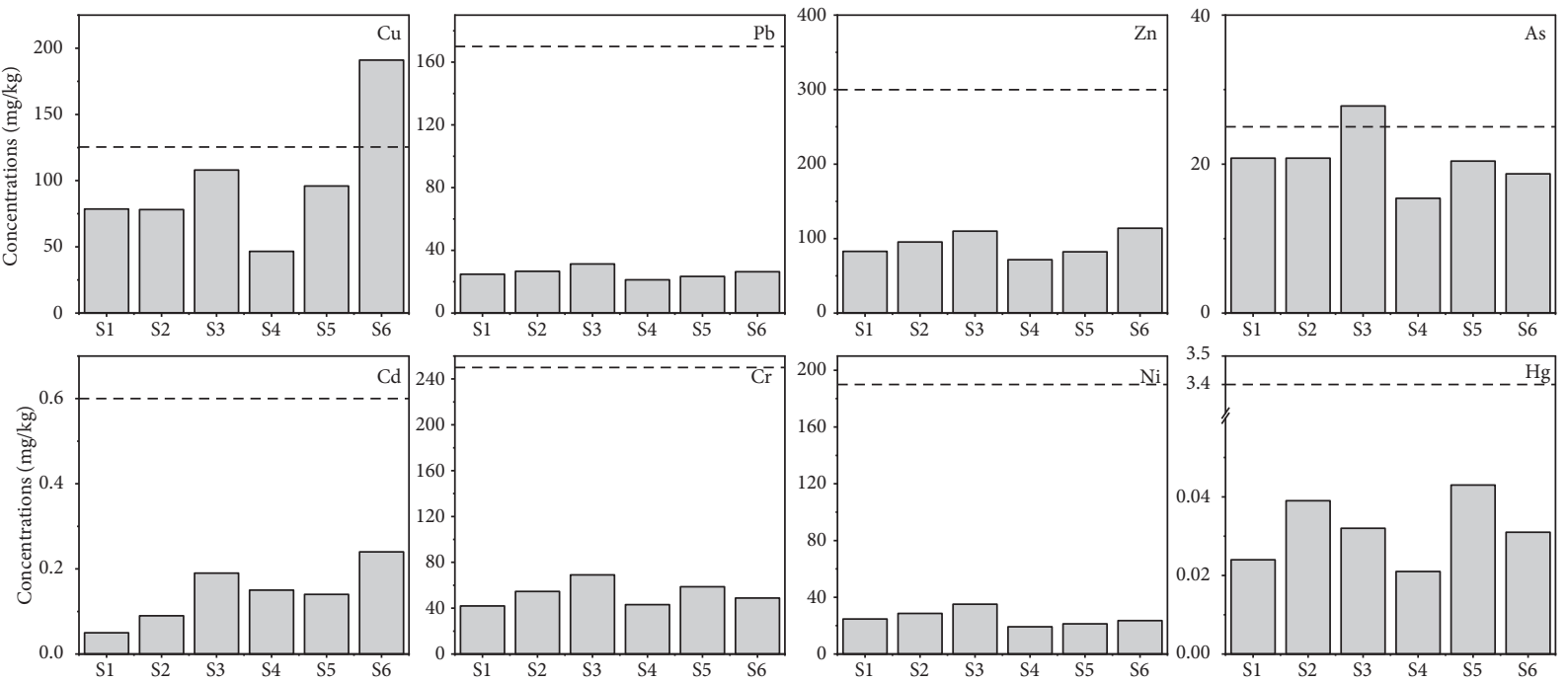

Figure 3: Heavy metal contents in the soils of the Tiegelongnan copper deposit area.

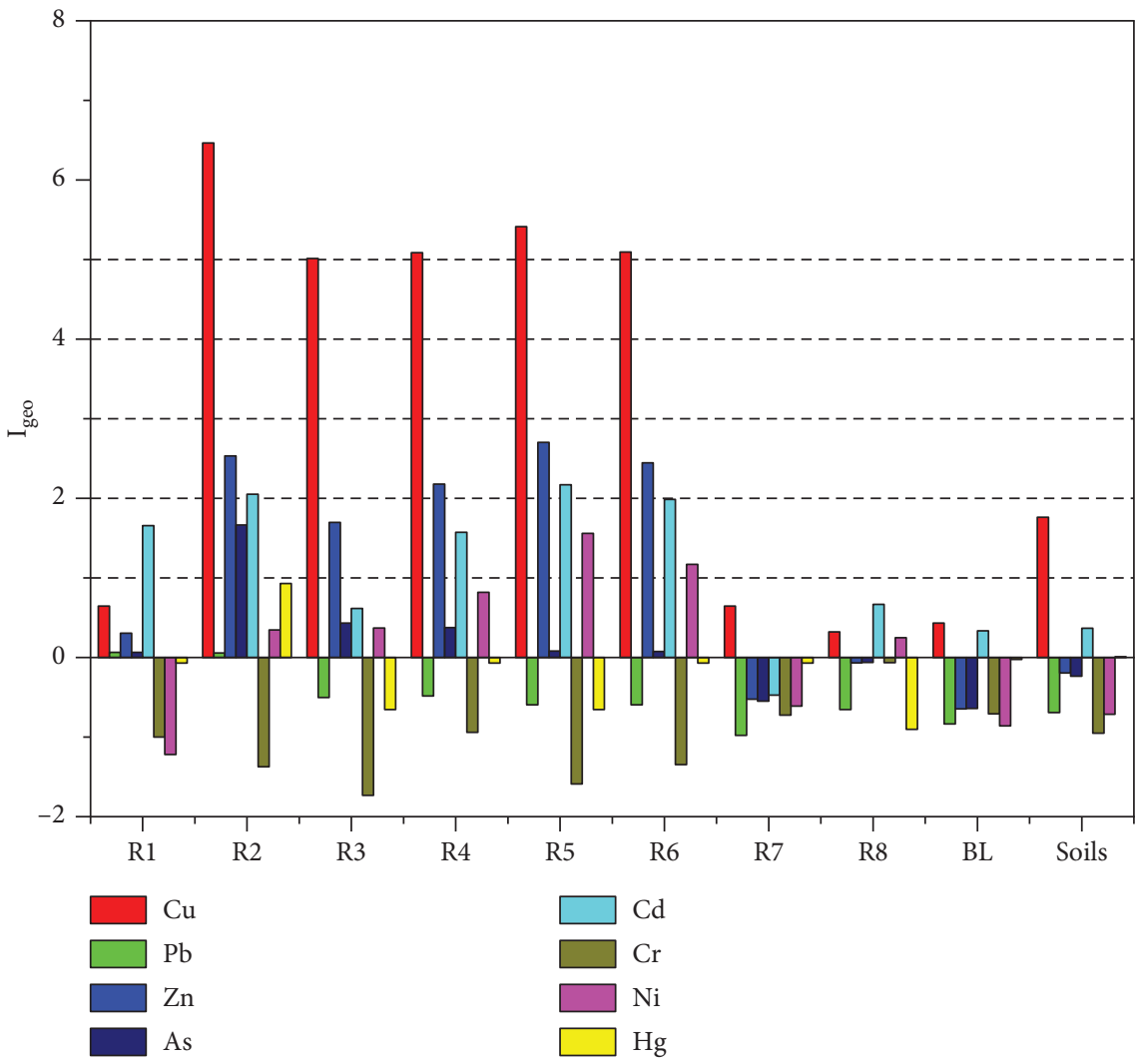

FIGURE 4: $I_{\text {Geo }}$ distribution of heavy metals in the study area.

point in the study area. Results indicate that the PER of Cd in $\mathrm{R} 1$ was high, the PER of $\mathrm{Hg}$ was moderate, and the $E_{r}^{i}$ of $\mathrm{Cu}$, $\mathrm{Zn}, \mathrm{Pb}, \mathrm{Cr}$, As, and $\mathrm{Ni}$ in $\mathrm{R} 1$ belonged to the low-risk range. In R2-R6, the value of $E_{r}^{i}$ of $\mathrm{Cu}$ was 347.09, which indicated that there was a significantly high potential ecological risk of
$\mathrm{Cu}$ in the sediments in R2-R6 of the Rongna River. The average value of $E_{r}^{i}$ of $\mathrm{Cd}$ was 154.05 , indicating a considerable potential ecological risk, and the average $E_{r}^{i}$ of $\mathrm{Hg}$ was 60.95 , indicating a moderate potential ecological risk. In the sediments of $\mathrm{R} 7$ and $\mathrm{R} 8$, the $E_{r}^{i}$ values of $\mathrm{Cd}$ and $\mathrm{Hg}$ 


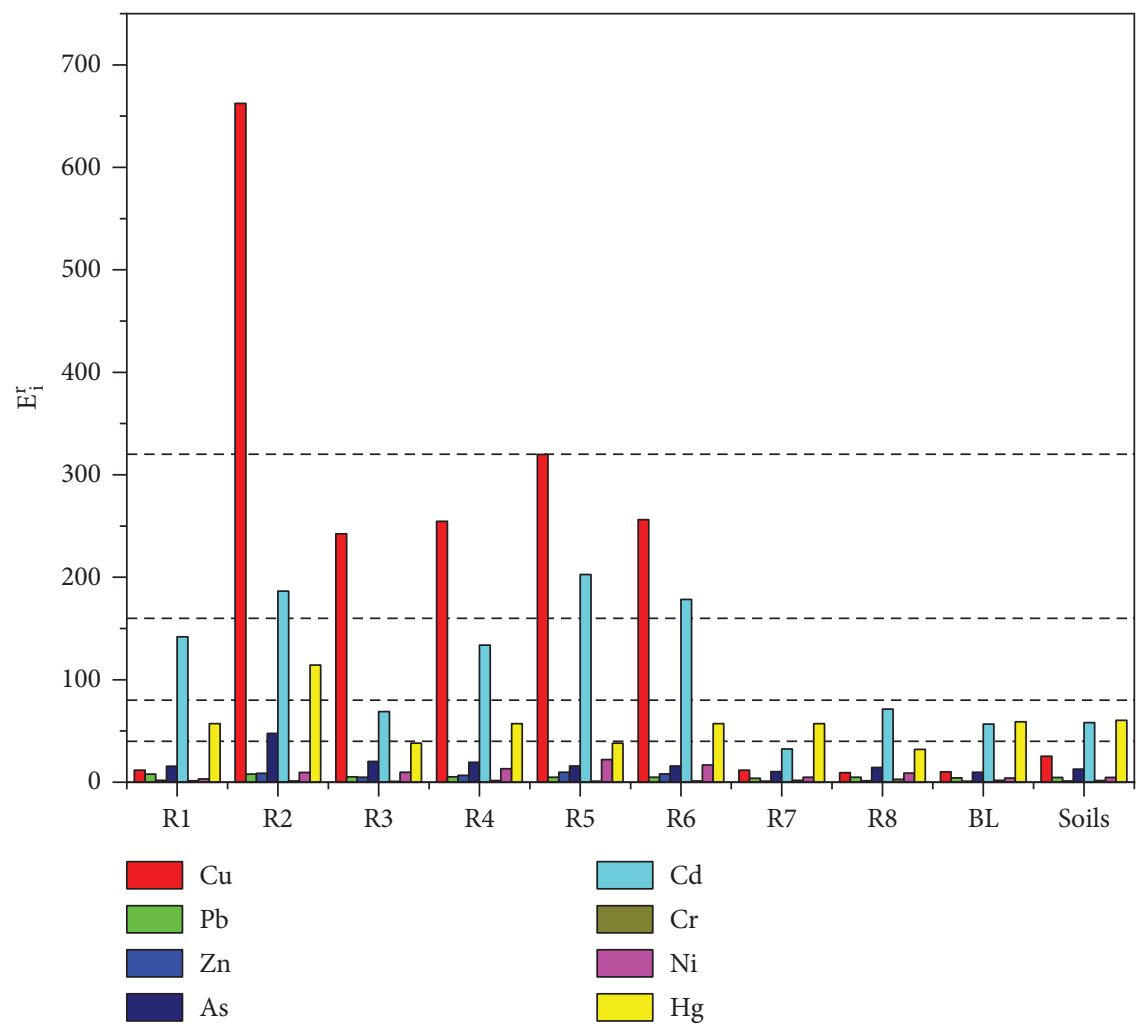

Figure 5: The potential ecological risk index of sediments and soil.

TABLE 5: Potential ecological RI for heavy metals in sediments and soil.

\begin{tabular}{lccccccccc}
\hline Sampling sites & $\mathrm{Cu}$ & $\mathrm{Pb}$ & $\mathrm{Zn}$ & $\mathrm{As}$ & $\mathrm{Cd}$ & $\mathrm{Cr}$ & $\mathrm{Ni}$ & $\mathrm{Hg}$ & $\mathrm{RI}$ \\
\hline R1 & 11.73 & 7.84 & 1.85 & 15.68 & 141.89 & 1.50 & 3.22 & 57.14 \\
R2 & 662.50 & 7.81 & 8.67 & 47.59 & 186.49 & 1.16 & 9.53 & 114.29 & $1,038.03$ \\
R3 & 242.35 & 5.29 & 4.87 & 20.25 & 68.92 & 0.90 & 9.69 & 38.10 & 390.36 \\
R4 & 254.59 & 5.36 & 6.79 & 19.44 & 133.78 & 1.56 & 13.24 & 57.14 & 491.91 \\
R5 & 319.90 & 4.96 & 9.76 & 15.86 & 202.70 & 1.00 & 22.12 & 38.10 & 614.40 \\
R6 & 256.12 & 4.96 & 8.18 & 15.80 & 178.38 & 1.18 & 16.87 & 57.14 \\
R7 & 11.73 & 3.80 & 1.04 & 10.25 & 32.43 & 1.81 & 4.91 & 57.14 \\
R8 & 9.38 & 4.76 & 1.43 & 14.37 & 71.41 & 2.87 & 8.90 & 32.09 & 123.13 \\
Soils & 25.43 & 4.64 & 1.31 & 12.75 & 58.11 & 1.55 & 4.57 & 60.32 \\
\hline
\end{tabular}

indicated moderate potential ecological risks, and other heavy metals showed low potential ecological risks. The $E_{r}^{i}$ values of $\mathrm{Cd}$ and $\mathrm{Hg}$ in the Bolong River indicated a moderate potential ecological risk. The $E_{r}^{i}$ value of the sediment in the Bolong River was close to R1, R7, and R8 and was much smaller than that of R2-R6, which indicated that the exposed minerals posed a serious potential ecological risk to the Rongna River. The $E_{r}^{i}$ values of $\mathrm{Cd}$ and $\mathrm{Hg}$ in soils indicated a moderate potential ecological risk, and other heavy metals in soil showed a low potential ecological risk.
Figure 6 shows the percentage of contribution of each heavy metal to HI. The potential ecological risk index RI of the eight heavy metals ranges from 123.12 to 1038.03 , with significant changes. The value of RI showed a moderate potential ecological risk. In R1, Cd contributed the most to $\mathrm{RI}$, followed by Hg. The R2-R6 section has an average RI of 614.67, which indicates strong pollution. The heavy metal that contributes the most to $\mathrm{RI}$ is $\mathrm{Cu}$, with an average contribution rate of $55.45 \%$, followed by $\mathrm{Cd}$ and $\mathrm{Hg}$. R7 and $\mathrm{R} 8$ are slightly polluted, and the soil in the mining area is 


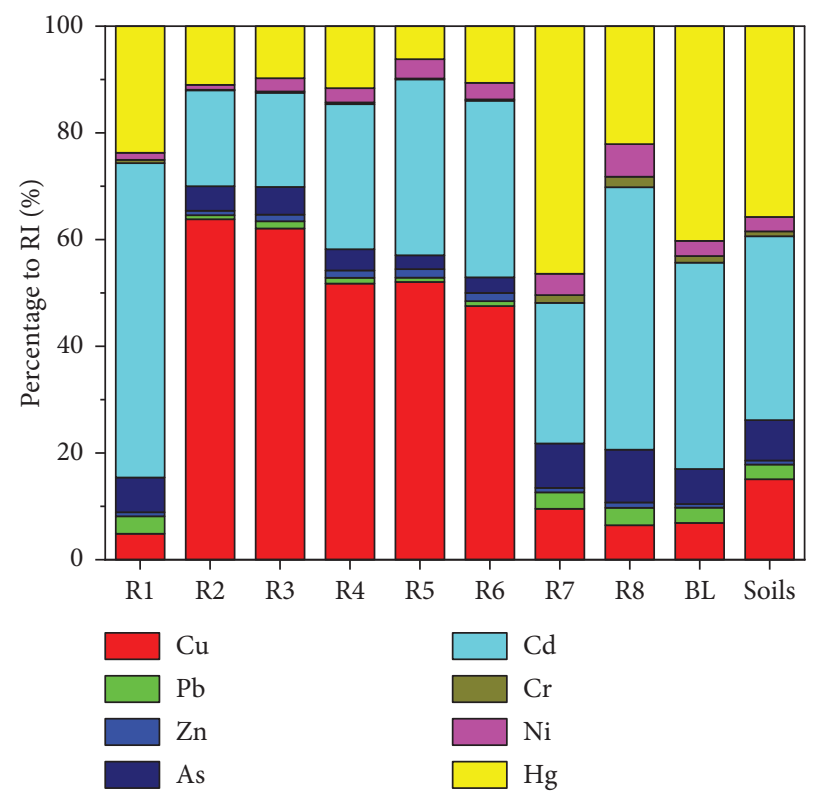

Figure 6: Contribution percentage of each heavy metal to HI.

moderately polluted. In R2-R6, the average RI was 614.67 , and R2-R6 indicated a high potential ecological risk. The heavy metal that contributed the most to the RI was $\mathrm{Cu}$, with an average contribution rate of $55.45 \%$, followed by $\mathrm{Cd}$ and Hg. The RI values of R7, R8, and soil indicated low ecological risk, and the heavy metals with higher RI were $\mathrm{Cd}$ and $\mathrm{Hg}$.

Previous studies have shown that the mining of minerals would cause a large amount of heavy metal pollution. A large amount of slag and tailings are exposed to the air during the mining process, and a large amount of heavy metal pollution is discharged into the river, causing serious river pollution $[39,40]$. The unexploited Tiegelongnan copper deposit is in the sparsely populated area of northern Tibet. It is almost unaffected by human activities. Heavy metal pollution caused only by the weathering of minerals has not caused serious pollution problems in rivers away from mining areas, which showed that the pollution generated in the natural state was within the self-purification range of the Rongna River.

4.4. Health Risk Assessment. Poisonous and harmful heavy metals, namely, $\mathrm{Cu}, \mathrm{Zn}, \mathrm{Cd}, \mathrm{Cr}, \mathrm{As}, \mathrm{Ni}, \mathrm{Cu}$, and $\mathrm{Hg}$, in the sediments and soils of the mining area, are exposed to the environment for a long time and pose carcinogenic and noncarcinogenic risks to humans continuously through oral ingestion, skin contact, and air inhalation [53, 59].

Figure 7 shows the calculation results of the hazard quotient (HQ) and hazard index (HI) in the sediments of the Rongna River and the soil in the mining area. The noncarcinogenic risk of each element is ranked as follows: $\mathrm{As}>\mathrm{Cr}>\mathrm{Cu}>\mathrm{Pb}>\mathrm{Ni}>\mathrm{Zn}>\mathrm{Cd}>\mathrm{Hg}$. The noncarcinogenic risk of heavy metals to children is higher than that of adults, which may be related to the daily behavior and physiological activities of children [64]. When the HQ and HI values are less than 1 , there is no obvious risk to humans, but if these values exceed 1, they may cause potential noncarcinogenic effects. The calculated HQ values of heavy metals in the sediments of the Rongna River and the soil of the mining area were between $2.47 \times 10^{-8}$ and $7.44 \times 10^{-1}$, and the HI values for both children and adults were less than 1 , which indicated that long-term exposure to the sediments and soil in the mining area would not pose a noncarcinogenic risk to the human body. This showed that in the absence of human interference, heavy metal pollution of sediments and soils in mining areas does not cause serious noncarcinogenic risks to the human body [65].

Figure 8 shows the CR and TCR values of heavy metal elements in sediments and soil. The average CR of each element is ranked as $\mathrm{As}>\mathrm{Cd}>\mathrm{Pb}>\mathrm{Cr}>\mathrm{Ni}$. Among them, As contributes the most to the total carcinogenic risk, which is similar to previous studies [66]. According to previous studies, when CR is less than $10^{-6}$, there is no obvious health risk; when CR is between $10^{-6}$ and $10^{-4}$, it is an acceptable risk range; and when $\mathrm{CR}$ is greater than $10^{-4}$, it is an unacceptable risk. As shown in Figure 8, the CR of ingestion and TCR of As in sediment R2 to children was greater than $10^{-4}$, which indicated that it poses a certain carcinogenic risk to children exposed to the area. The average TCRs of As and $\mathrm{Cd}$ in sediments and As in soil are between $10^{-6}$ and $10^{-4}$, which is an acceptable risk range [67]. However, according to the National Environmental Protection Standard [54], a single pollutant TCR greater than $10^{-6}$ is an unacceptable risk, and the TCRs of As and Cd in the sediments and As in the soil of the study area were greater than $10^{-6}$, which indicated that As and Cd in the sediments and As in the soil pose a certain carcinogenic risk to humans. It is recommended that children and adults avoid long-term activities in mining areas. 

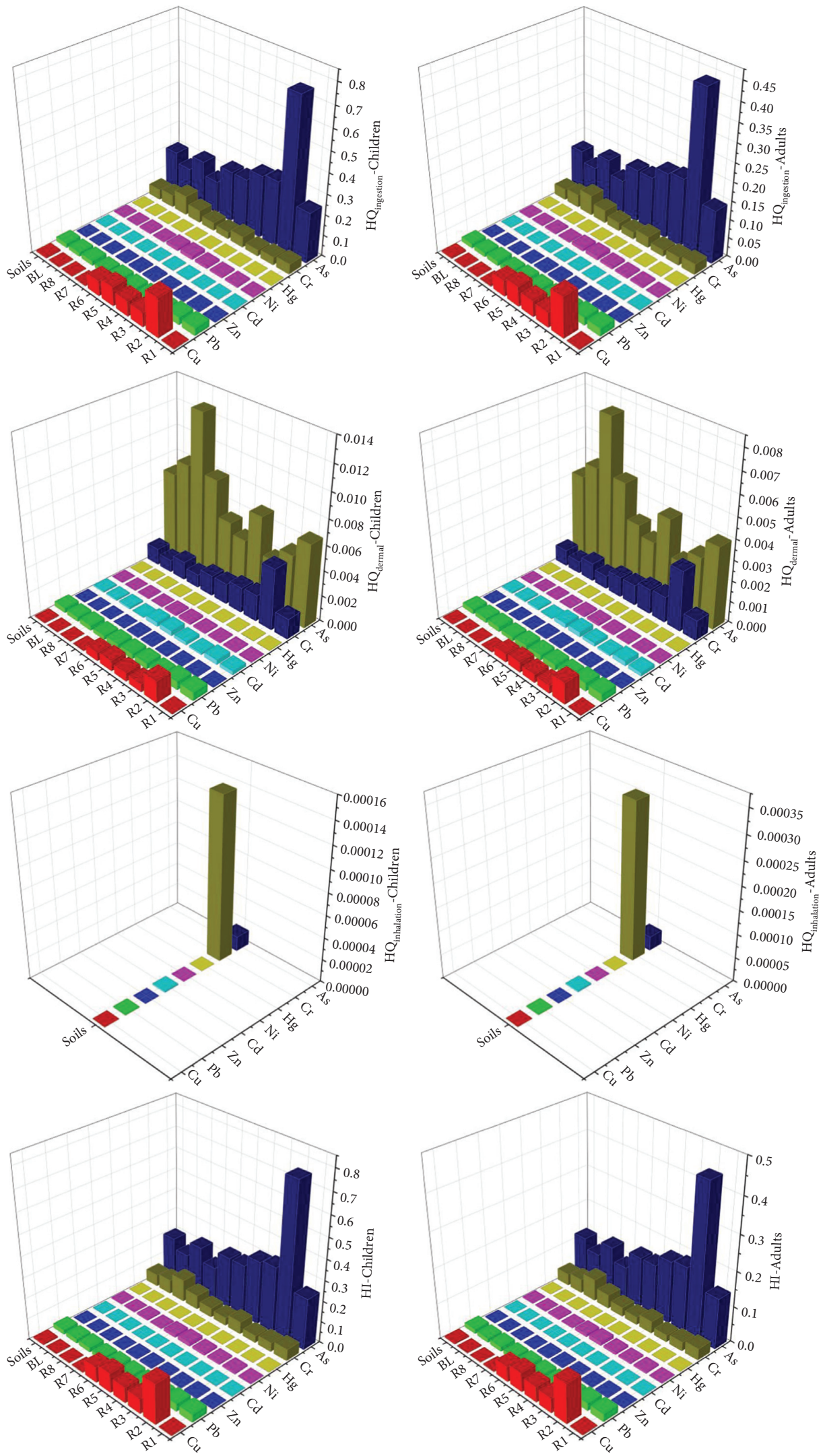

FIgURE 7: The hazard quotient (HQ) and hazard index (HI) of the study area in sediments and soils. 

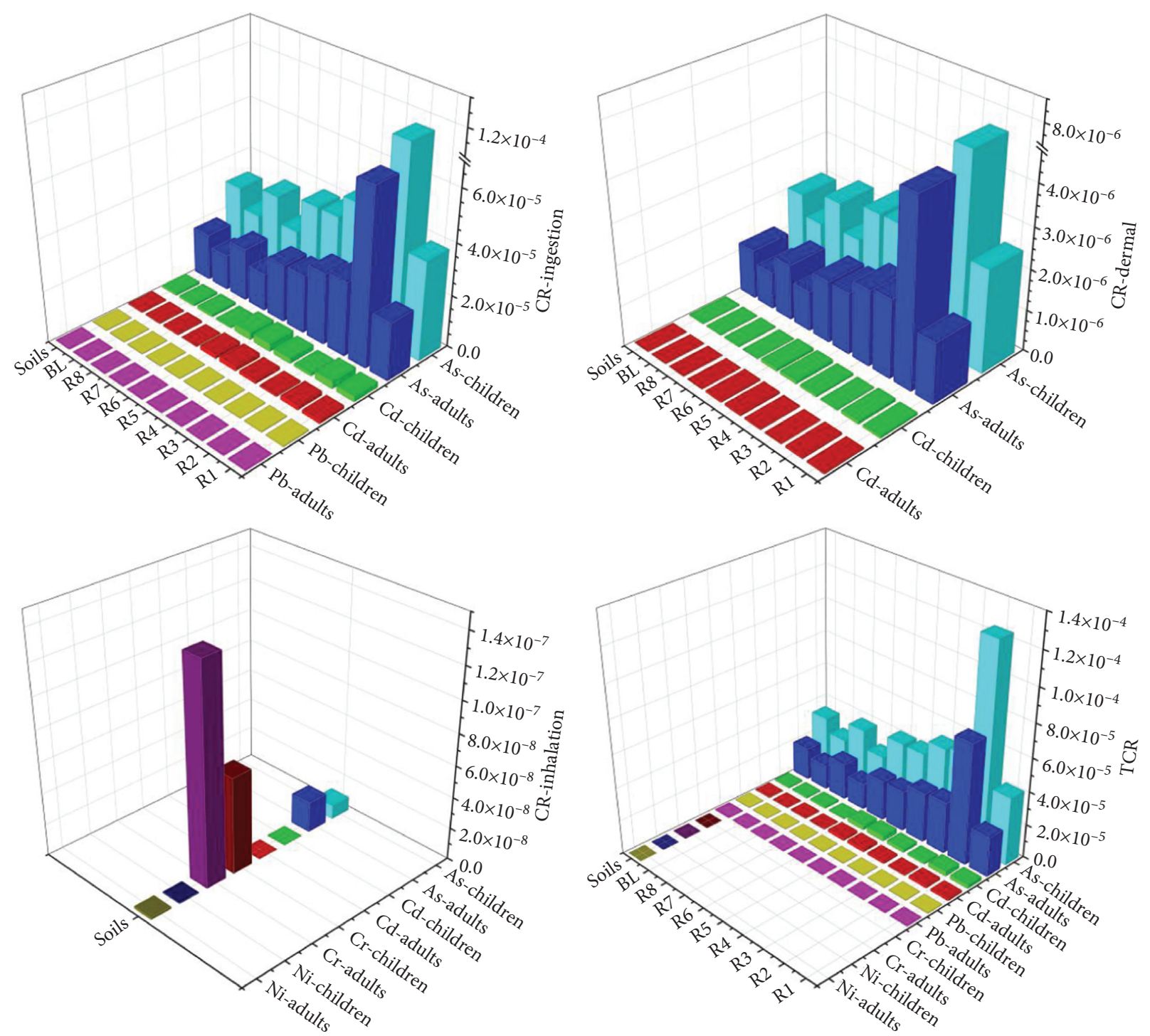

FIgURE 8: The carcinogenic risk (CR) and total carcinogenic risk index (TCR) of the study area in sediments and soils.

\section{Conclusions}

The concentrations of $\mathrm{Cu}, \mathrm{Zn}, \mathrm{As}, \mathrm{Cd}, \mathrm{Ni}$, and $\mathrm{Hg}$ in the surface sediments of the Rongna River entering the Tiegelongnan copper deposit area had a significant upward trend and were greater than the concentrations of heavy metals in the surface sediments of the Bolong River, and the concentrations of $\mathrm{Cu}, \mathrm{Zn}$, and As exceeded the Grade II national environmental quality standard. The average concentrations of heavy metals in the soil of the $\mathrm{Cu}$ deposit area were higher than the element background value of soil in Tibet but lower than the corresponding Grade II national environmental quality standard.

The geoaccumulation index showed that the sediments in the river section entering the mining area were very highly polluted by $\mathrm{Cu}$ and moderately polluted by $\mathrm{Cd}$ and $\mathrm{Zn}$, and the soils in the mining area were moderately polluted by $\mathrm{Cu}$. The potential ecological risk index (RI) values in the surface sediments of the Rongna River were between 123.12 and 1,038.03. At the R1 sampling point of the Rongna River, the potential ecological risk was moderate. The R2-R6 section showed a high potential ecological risk, but there was no serious potential ecological risk of heavy metal pollution in the section far away from the deposit area, and the results indicated that the heavy metal pollution naturally produced by the deposit was within the self-purification capacity of the Rongna River. The results of the health risk assessment indicated that the noncarcinogenic risks of heavy metals in sediments and soil of the Rongna $\mathrm{Cu}$ deposit area were within the acceptable range for adults and children. However, the carcinogenic risk of As and Cd in the sediment and As in the soil exceeds the relevant national standards, which may pose a certain risk to human health.

\section{Data Availability}

The datasets used or analyzed during the current study are available from the corresponding author on reasonable request. 


\section{Conflicts of Interest}

The authors declare that there are no conflicts of interest.

\section{Authors' Contributions}

Qinxian Jia and Yuhu Luo contributed to sample collection and data analysis and were responsible for methodology; Yuhu Luo prepared the original draft and reviewed and edited the manuscript. All authors have read and agreed to the published version of the manuscript.

\section{References}

[1] X. Li, O. W. H. Wai, Y. S. Li, B. J. Coles, M. H. Ramsey, and I. Thornton, "Heavy metal distribution in sediment profiles of the Pearl River Estuary, South China," Applied Geochemistry, vol. 15, no. 5, pp. 567-581, 2000.

[2] C. S. C. Wong, X. D. Li, G. Zhang, S. H. Qi, and X. Z. Peng, "Atmospheric deposition of heavy metals in the Pearl River Delta, China," Atmospheric Environment, vol. 37, no. 6, pp. 767-776, 2003.

[3] E. Solgi, A. Esmaili-Sari, A. Riyahi-Bakhtiari, and M. Hadipour, "Soil contamination of metals in the three industrial estates, Arak, Iran," Bulletin of Environmental Contamination and Toxicology, vol. 88, no. 4, pp. 634-638, 2012.

[4] Z. Li, Z. Ma, T. J. Van Der Kuijp, Z. Yuan, and L. Huang, “A review of soil heavy metal pollution from mines in China: pollution and health risk assessment," The Science of the Total Environment, vol. 468-469, pp. 843-853, 2014.

[5] A. Burges, L. Epelde, and C. Garbisu, "Impact of repeated single-metal and multi-metal pollution events on soil quality," Chemosphere, vol. 120, pp. 8-15, 2015.

[6] M. Guney, G. J. Zagury, N. Dogan, and T. T. Onay, "Exposure assessment and risk characterization from trace elements following soil ingestion by children exposed to playgrounds, parks and picnic areas," Journal of Hazardous Materials, vol. 182, no. 1-3, pp. 656-664, 2010.

[7] E. P. Nobi, E. Dilipan, T. Thangaradjou, K. Sivakumar, and L. Kannan, "Geochemical and geo-statistical assessment of heavy metal concentration in the sediments of different coastal ecosystems of Andaman Islands, India," Estuarine, Coastal and Shelf Science, vol. 87, no. 2, pp. 253-264, 2010.

[8] T. W. Lane and F. M. M. Morel, "A biological function for cadmium in marine diatoms," Proceedings of the National Academy of Sciences, vol. 97, no. 9, pp. 4627-4631, 2000.

[9] X. Liu, Q. Song, Y. Tang et al., "Human health risk assessment of heavy metals in soil-vegetable system: a multi-medium analysis," The Science of the Total Environment, vol. 463-464, pp. 530-540, 2013.

[10] W. P. Tseng, H. M. Chu, S. W. How, J. M. Fong, C. S. Lin, and S. Yeh, "Prevalence of skin cancer in an endemic area of chronic arsenicism in Taiwan," Journal of the National Cancer Institute, vol. 40, no. 3, pp. 453-463, 1968.

[11] M. E. Cebrian, A. Albores, M. Aguilar, and E. Blakely, "Chronic arsenic poisoning in the North of Mexico," Human Toxicology, vol. 2, no. 1, pp. 121-133, 1983.

[12] A. K. Chakraborty and K. C. Saha, "Arsenical dermatosis from tubewell water in West-Bengal," Indian Journal of Medical Research, vol. 85, pp. 326-334, 1987.

[13] R. Zaldívar, "Arsenic contamination of drinking water and foodstuffs causing endemic chronic poisoning," Beiträge Zur Pathologie, vol. 151, no. 4, pp. 384-400, 1974.
[14] D. Mergler, H. A. Anderson, L. H. M. Chan et al., "Methylmercury exposure and health effects in humans: a worldwide concern," AMBIO: A Journal of the Human Environment, vol. 36, no. 1, pp. 3-11, 2007.

[15] M. P. Iqbal, "Lead pollution-a risk factor for cardiovascular disease in Asian developing countries," Pakistan Journal of Pharmaceutical Sciences, vol. 25, no. 1, pp. 289-294, 2012.

[16] Z. Chen, X. Huo, G. Chen, X. Luo, and X. Xu, "Lead (Pb) exposure and heart failure risk," Environmental Science and Pollution Research International, vol. 28, no. 23, pp. 2883328847, 2021.

[17] Q. Pasha, S. A. Malik, N. Shaheen, and M. H. Shah, "Investigation of trace metals in the blood plasma and scalp hair of gastrointestinal cancer patients in comparison with controls," Clinica Chimica Acta; International Journal of Clinical Chemistry, vol. 411, no. 7-8, pp. 531-539, 2010.

[18] X. Wang, W. Cui, M. Wang et al., "The association between life-time dietary cadmium intake from rice and chronic kidney disease," Ecotoxicology and Environmental Safety, vol. 211, 2021.

[19] A. Engström, K. Michaëlsson, M. Vahter, B. Julin, A. Wolk, and A. Åkesson, "Associations between dietary cadmium exposure and bone mineral density and risk of osteoporosis and fractures among women," Bone, vol. 50, no. 6, pp. 1372-1378, 2012.

[20] L. D. Thomas, K. Michaëlsson, B. Julin, A. Wolk, and A. Åkesson, "Dietary cadmium exposure and fracture incidence among men: a population-based prospective cohort study," Journal of Bone and Mineral Research, vol. 26, no. 7, pp. 1601-1608, 2011.

[21] D. Abeck, I. Traenckner, V. Steinkraus, D. Vieluf, and J. Ring, "Chronic urticaria due to nickel intake," Acta DermatoVenereologica, vol. 73, no. 6, pp. 438-439, 1993.

[22] R. Mittal, P. Gupta, D. J. Dash, R. Prasad, and S. K. Chhabra, "Occupational emphysema following long-term exposure to metal fumes during electroplating in a non-smoker," Indian Journal of Chest Diseases and Allied Sciences, vol. 58, no. 2, pp. 123-125, 2016.

[23] Ü. Gül, S. K. Çakmak, I. Olcay, A. Gönül, and M. Gonul, "Nickel sensitivity in asthma patients," Journal of Asthma, vol. 44, no. 5, pp. 383-384, 2007.

[24] S. R. Berge and K. Skyberg, "Radiographic evidence of pulmonary fibrosis and possible etiologic factors at a nickel refinery in Norway," Journal of Environmental Monitoring, vol. 5, no. 4, pp. 681-688, 2003.

[25] C. Zhang, Z.-G. Yu, G.-M. Zeng et al., "Effects of sediment geochemical properties on heavy metal bioavailability," Environment International, vol. 73, pp. 270-281, 2014.

[26] G. Du Laing, J. Rinklebe, B. Vandecasteele, E. Meers, and F. M. G. Tack, "Trace metal behaviour in estuarine and riverine floodplain soils and sediments: a review," The Science of the Total Environment, vol. 407, no. 13, pp. 3972-3985, 2009.

[27] H. Cao, J. Chen, J. Zhang, H. Zhang, L. Qiao, and Y. Men, "Heavy metals in rice and garden vegetables and their potential health risks to inhabitants in the vicinity of an industrial zone in Jiangsu, China," Journal of Environmental Sciences, vol. 22, no. 11, pp. 1792-1799, 2010.

[28] H. Ghrefat and N. Yusuf, “Assessing Mn, Fe, Cu, Zn, and Cd pollution in bottom sediments of Wadi Al-Arab Dam, Jordan," Chemosphere, vol. 65, no. 11, pp. 2114-2121, 2006.

[29] Z. He, F. Li, S. Dominech, X. Wen, and S. Yang, "Heavy metals of surface sediments in the Changjiang (Yangtze River) Estuary: distribution, speciation and environmental risks," Journal of Geochemical Exploration, vol. 198, pp. 18-28, 2019. 
[30] B. Keshavarzi, M. Hassanaghaei, F. Moore et al., "Heavy metal contamination and health risk assessment in three commercial fish species in the Persian Gulf," Marine Pollution Bulletin, vol. 129, no. 1, pp. 245-252, 2018.

[31] J. J. Rogers, W. F. Henley, A. G. Weberg, J. W. Jones, and W. Gregory Cope, "Assessment of growth, survival, and organ tissues of caged mussels (Bivalvia: unionidae) in a river-scape influenced by coal mining in the southeastern USA," The Science of the Total Environment, vol. 645, pp. 1273-1286, 2018.

[32] T. B. Chen, J. W. C. Wong, H. Y. Zhou, and M. H. Wong, "Assessment of trace metal distribution and contamination in surface soils of Hong Kong," Environmental Pollution, vol. 96, no. 1, pp. 61-68, 1997.

[33] M. M. Meza-Montenegro, A. J. Gandolfi, M. E. SantanaAlcántar et al., "Metals in residential soils and cumulative risk assessment in Yaqui and Mayo agricultural valleys, Northern Mexico," The Science of the Total Environment, vol. 433, pp. 472-481, 2012.

[34] R. Li, Y. Yang, and Y. Meng, "Main results and progress in 1: 250000 regional geological survey of the northern QinghaiTibet Plateau," Geological Bulletin of China, vol. 23, no. 5/6, pp. 421-426, 2004.

[35] L. Liu, F. Yao, J. Wu, J. Yang, and X. Geng, “Application of multi-source data to mineral exploration in Tibetan Duolong ore concentration," Journal of Beijing Normal University, vol. 52, no. 2, pp. 184-188, 2016.

[36] D. Zhu, Y. Wei, Y. Zhao, Q. Wang, and J. Han, "Heavy metal pollution and ecological risk assessment of the agriculture soil in Xunyang mining area, Shaanxi province, Northwestern China," Bulletin of Environmental Contamination and Toxicology, vol. 101, no. 2, pp. 178-184, 2018.

[37] L. Rodríguez, E. Ruiz, J. Alonso-Azcárate, and J. Rincón, "Heavy metal distribution and chemical speciation in tailings and soils around a $\mathrm{Pb}-\mathrm{Zn}$ mine in Spain," Journal of Environmental Management, vol. 90, no. 2, pp. 1106-1116, 2009.

[38] C.-Y. Yuan, F.-Y. Li, Z.-Q. Yuan et al., "Distribution characteristics and pollution evaluation of heavy metals in an extremely cold and high-altitude mining area in Xinjiang," Journal of Ecology and Rural Environment, vol. 36, no. 5, pp. 679-688, 2020.

[39] H.-M. Ye, X.-Y. Yuan, and J. Zhao, "Spatial migration and environmental effects of heavy metals in river sediments from in the Tongling mining area, Anhui province," China Environmental Science, vol. 32, no. 10, pp. 1853-1859, 2012.

[40] X.-H. Li, P. Xu, J.-Q. Li, R.-Y. Cao, H. Fan, and Y.-Y. Gao, "Heavy metal pollution of surface sediment in dachang mine area of Guangxi and its ecological risk assessment," Journal of North University of China (Natural Science Edition), vol. 33, no. 2, pp. 190-196, 2012.

[41] J. Tang, Y. Song, Q. Wang et al., "Geological characteristics and exploration model of the tiegelongnan $\mathrm{Cu}(\mathrm{Au}-\mathrm{Ag}) \mathrm{de}-$ posit: the first ten million tons metal resources of a porphyryepithermal deposit in Tibet," Acta Geoscientia Sinica, vol. 37, no. 6, pp. 663-690, 2016.

[42] B. Peng, Z. Song, X. Tu, M. Xiao, F. Wu, and H. Lv, "Release of heavy metals during weathering of the lower cambrian black Shales in western Hunan, China," Environmental Geology, vol. 45, no. 8, pp. 1137-1147, 2004.

[43] B. Elberling and B. R. Langdahl, "Note: natural heavy-metal release by sulphide oxidation in the high Arctic," Canadian Geotechnical Journal, vol. 35, no. 5, pp. 895-901, 1998.

[44] W. Li, D. Bu, J. Sun, Z. Shan, X. Lv, and J. Xiong, "Distribution and ecological risk assessment of heavy metal elements in the surface sediments of Bagaxue wetlands in Lhasa," Huanjing Huaxue-Environmental Chemistry, vol. 40, no. 1, pp. 195-203, 2021.

[45] Z. Qiongda, J. Wayg, W. Zhou, P. Zhou, D. Meng, and Z. Dan, "Analysis and evaluation of heavy metal content in soil around leachate treatment station of lhasa landfill site," Huanjing Huaxue-Environmental Chemistry, vol. 39, no. 5, pp. 1404-1409, 2020.

[46] H. Xie, J. Li, C. Zhang et al., "Assessment of heavy metal contents in surface soil in the Lhasa-Shigatse-Nam co area of the Tibetan Plateau, China," Bulletin of Environmental Contamination and Toxicology, vol. 93, no. 2, pp. 192-198, 2014.

[47] C. Lin, M. He, Y. Zhou, W. Guo, and Z. Yang, "Distribution and contamination assessment of heavy metals in sediment of the second Songhua River, China," Environmental Monitoring and Assessment, vol. 137, no. 1-3, pp. 329-342, 2008.

[48] S. Lu, Y. Wang, Y. Teng, and X. Yu, "Heavy metal pollution and ecological risk assessment of the paddy soils near a zinclead mining area in Hunan," Environmental Monitoring and Assessment, vol. 187, no. 10, p. 627, 2015.

[49] G. Muller, "Index of geoaccumulation in sediments of the Rhine river," Geojournal, vol. 2, pp. 108-118, 1969.

[50] X. P. zhang, "Research on the environmental background values of soils in Xizang," Scientia Geographica Sinica, vol. 14, no. 1, p. 49, 1994.

[51] L. Hakanson, "An ecological risk index for aquatic pollution control.a sedimentological approach," Water Research, vol. 14, no. 8, pp. 975-1001, 1980.

[52] A. Pelfrêne, F. Douay, A. Richard, H. Roussel, and B. Girondelot, "Assessment of potential health risk for inhabitants living near a former lead smelter. Part 2: site-specific human health risk assessment of $\mathrm{Cd}$ and $\mathrm{Pb}$ contamination in kitchen gardens," Environmental Monitoring and Assessment, vol. 185, no. 4, pp. 2999-3012, 2013.

[53] J. Song, Q. Liu, and Y. Sheng, "Distribution and risk assessment of trace metals in riverine surface sediments in gold mining area," Environmental Monitoring and Assessment, vol. 191, no. 3, p. 191, 2019.

[54] Ministry of Environmental Protection of the People's Republic of China, Technical Guidelines for Risk Assessment of Contaminated, HJ 25.3-2014, China Environmental Science Press, Beijing, China, 2014.

[55] USEPA, Risk Assessment Guidance for Superfund Volume I: Human Health Evaluation Manual, Office of Emergency and Remedial Response, Washington, DC, USA, 1989.

[56] USEPA, Soil Screening guidance: Technical Background Document, USEPA, Washington, DC, USA, 1996.

[57] USEPA, Supplemental Guidance for Developing Soil Screening Levels for Superfund Sites, Office of Emergency and Remedial Response, Washington, DC, USA, 2002.

[58] Y.-G. Gu, Y.-P. Gao, and Q. Lin, "Contamination, bioaccessibility and human health risk of heavy metals in exposed-lawn soils from 28 urban parks in southern China's largest city, Guangzhou," Applied Geochemistry, vol. 67, pp. 52-58, 2016.

[59] S. H. Huang, Q. Li, Y. Yang, C. Y. Yuan, K. Ouyang, and P. You, "Risk assessment of heavy metals in soils of a lead-zinc mining area in Hunan province (China)," Kemija U IndustrijiJournal of Chemists and Chemical Engineers, vol. 66, no. 3-4, pp. 173-178, 2017.

[60] J. L. Marrugo-Negrete, I. D. Urango-Cardenas, S. M. B. Núñez, and S. Díez, "Atmospheric deposition of heavy metals in the mining area of the San Jorge river basin, 
Colombia," Air Quality, Atmosphere \& Health, vol. 7, no. 4, pp. 577-588, 2014.

[61] C. R. Cánovas, J. Riera, S. Carrero, and M. Olías, "Dissolved and particulate metal fluxes in an AMD-affected stream under different hydrological conditions: the Odiel River (SW Spain)," Catena, vol. 165, pp. 414-424, 2018.

[62] K. A. Hudson-Edwards, M. G. Macklin, C. D. Curtis, and D. J. Vaughan, "Processes of formation and distribution of $\mathrm{Pb}$ , Zn-, Cd-, and Cu-bearing minerals in the Tyne Basin, northeast England: implications for metal-contaminated river systems," Environmental Science \& Technology, vol. 30, no. 1, pp. 72-80, 1996.

[63] A. M. Sarmiento, J. M. Nieto, M. Cánovas, and C. R. Canovas, "Hydrochemical characteristics and seasonal influence on the pollution by acid mine drainage in the Odiel river Basin (SW Spain)," Applied Geochemistry, vol. 24, no. 4, pp. 697-714, 2009.

[64] Y. Jiang, S. Chao, J. Liu et al., "Source apportionment and health risk assessment of heavy metals in soil for a township in Jiangsu Province, China," Chemosphere, vol. 168, pp. 16581668, 2017.

[65] G. U. Chibuike and S. C. Obiora, "Heavy metal polluted soils: effect on plants and bioremediation methods," Applied and Environmental Soil Science, vol. 2014, Article ID 752708, 2014.

[66] C. Kamunda, M. Mathuthu, and M. Madhuku, "Health risk assessment of heavy metals in soils from witwatersrand gold mining basin, South Africa," International Journal of Environmental Research and Public Health, vol. 13, no. 7, 2016.

[67] M. Fryer, C. D. Collins, H. Ferrier, R. N. Colvile, and M. J. Nieuwenhuijsen, "Human exposure modelling for chemical risk assessment: a review of current approaches and research and policy implications," Environmental Science \& Policy, vol. 9, no. 3, pp. 261-274, 2006. 